\title{
Optimasi nisbah natrium nitrat : urea dan konsentrasi nitrogen pada kultivasi Spirulina platensis untuk produksi protein dan pigmen fikosianin
}

\author{
Optimization of nitrate:urea ratio and nitrogen concentration on Spirulina platensis cultivation for the \\ production of protein and phycocyanin pigment
}

\section{Rizki KURNIAWATI ${ }^{1)}$, Swastika PRAHARYAWAN $\left.{ }^{2}\right) \&$ Tri-PANJI $^{\left.1,3)^{*}\right)}$}

\author{
${ }^{1)}$ Program Studi Kimia, Fakultas Matematika dan Ilmu Pengetahuan Alam, Universitas Pakuan Bogor, Jl. Pakuan PO Box \\ 452, Bogor 16610, Indonesia \\ 2)Pusat Penelitian Bioteknologi, Lembaga Ilmu Pengetahuan Indonesia (LIPI), Jl. Raya Bogor Km.46, Cibinong 16911, \\ Indonesia \\ ${ }^{3)}$ Pusat Penelitian Bioteknologi dan Bioindustri Indonesia, Jl. Taman Kencana No.1, Bogor 16128, Indonesia
}

Diterima tgl 18 Agustus 2020 / disetujui tgl 29 Oktober 2020

\begin{abstract}
The need of nitrogen (N) for the growth of Spirulina platensis and the production of protein and phycocyanin pigment is influenced by the type of source and the concentration of $N$ contained in the growing media. Spirulina platensis can assimilate various $N$ sources, including nitrate $\left(\mathrm{NO}_{3}{ }^{-}\right)$and urea. Urea is a cheap $\mathrm{N}$ source and easy to be obtained. Urea can also have a role as potential N source to support the growth and the metabolites production of cyanobacteria $\mathrm{S}$. platensis. Partial substitution of $\mathrm{N}$ source $\left(\mathrm{NO}_{3}^{-}\right)$to urea in Zarrouk medium for S. platensis cultivation has not been conducted before. This study was aiming at determining the optimum ratio of $\mathrm{NaNO}_{3}: \mathrm{CO}\left(\mathrm{NH}_{2}\right)_{2}$ and the optimum $\mathrm{N}$ concentration in the Zarrouk medium for protein and phycocyanin production by S. platensis. Response Surface Method (RSM)-one factor experimental design was employed in this study for determining the optimum $N$ concentration at specific $N$ concentration range and optimum ratio of $N$ source that had been previously determined. The results demonstrated that the optimum ratio of $\mathrm{NaNO}_{3}: \mathrm{CO}\left(\mathrm{NH}_{2}\right)_{2}$ for protein and phycocyanin production was 1:1. The optimum $N$ concentration for protein and phycocyanin pigment production in S. platensis cultivation were $5.13 \mathrm{mmol} L^{-1}$ and $4.94 \mathrm{mmol} \mathrm{L}^{-1}$ with the increament in about $51.95 \%$ and $25.16 \%$, respectively, compared to the standar Zarrouk medium.
\end{abstract}

[Keywords: Blue-green algae, Zarrouk medium, Response Surface Methodology-one factor, nitrogen source]

\section{Abstrak}

Kebutuhan unsur nitrogen (N) untuk pertumbuhan Spirulina platensis serta produksi protein dan pigmen fikosianin dipengaruhi oleh

*) Penulis korespondensi: rizkik1028@gmail.com jenis sumber dan konsentrasi $\mathrm{N}$ yang terkandung dalam media tumbuh. Spirulina platensis dapat mengasimilasi berbagai sumber $\mathrm{N}$, termasuk nitrat $\left(\mathrm{NO}_{3}{ }^{-}\right)$dan urea. Urea merupakan sumber $\mathrm{N}$ yang murah dan mudah diperoleh. Urea juga dapat berperan sebagai sumber $\mathrm{N}$ potensial untuk mendukung pertumbuhan dan produksi metabolit pada sianobakteria S. platensis. Substitusi sebagian sumber $\mathrm{N}\left(\mathrm{NaNO}_{3}\right)$ oleh urea dalam media Zarrouk untuk kultivasi $S$. platensis belum banyak dilakukan sebelumnya. Penelitian ini bertujuan untuk menentukan nisbah $\mathrm{NaNO}_{3}: \mathrm{CO}\left(\mathrm{NH}_{2}\right)_{2}$ dan konsentrasi $\mathrm{N}$ optimum yang diperlukan dalam media Zarrouk untuk produksi protein dan fikosianin oleh $S$. platensis. Desain eksperimen RSM-one factor digunakan dalam penentuan konsentrasi $\mathrm{N}$ optimum pada rentang konsentrasi $\mathrm{N}$ dan nisbah sumber $\mathrm{N}$ optimum yang telah ditentukan sebelumnya. Hasil penelitian menunjukkan bahwa nisbah $\mathrm{NaNO}_{3}: \mathrm{CO}\left(\mathrm{NH}_{2}\right)_{2}$ optimum untuk meningkatkan kandungan protein dan pigmen fikosianin $S$. platensis adalah 1:1. Konsentrasi $\mathrm{N}$ optimum untuk produksi protein dan pigmen fikosianin pada kultivasi $S$. platensis ialah 5,13 mmol L-1 dan 4,94 mmol L $\mathrm{m}^{-1}$ dengan peningkatan sebesar $51,95 \%$ dan $25,16 \%$, secara berturut-turut, bila dibandingkan dengan saat dikultivasi menggunakan media Zarrouk standar.

[Kata Kunci: Alga hijau-biru, medium Zarrouk, metode permukaan respon-satu faktor, sumber nitrogen]

\section{Pendahuluan}

Spirulina platensis merupakan mikroorganisme fotosintesis yang banyak dibudidayakan karena memiliki kandungan nutrisi yang tinggi, seperti protein, asam lemak, vitamin, mineral dan pigmen (Rodrigues et al., 2011; Madkour et al., 2012). Spirulina platensis dipercaya sebagai sumber protein alternatif 
karena biomassanya mengandung hingga 70\% protein dari berat keringnya (Avila-Leon et al., 2012). Spirulina platensis memiliki kompleks pigmen-protein yang dikenal dengan fikobiliprotein (Seo et al., 2013; Rahman et al., 2017). Fikobiliprotein mewakili pigmen aksesori fotosintesis bagi $S$. platensis yang terdiri dari fikoeritrin, fikosianin, dan alofikosianin (Saleh et al., 2011). Fikosianin merupakan fikobiliprotein utama dalam S. platensis (Chaiklahan et al., 2012), yang kandungannya dapat mencapai sekitar $20 \%$ dari berat keringnya dan secara kuantitatif merupakan pigmen paling dominan dalam $S$. platensis (Richmond, 1988).

Produktivitas biomassa serta konsentrasi bahan aktif $S$. platensis yang dihasilkan bergantung pada ketersediaan nutrien dalam medium tumbuhnya (Madkour et al., 2012; Sukumaran et al., 2018). Di antara komponen medium tumbuhnya, $\mathrm{N}$ dianggap sebagai nutrien paling penting bagi laju pertumbuhan dan sintesis sel $S$. platensis, karena N merupakan unsur mendasar bagi pembentukan protein struktural dan fungsional seperti enzim, klorofil, molekul transfer energi, asam nukleat, dan bahan genetik lain dalam sel mikroalga (Bao et al., 2012; Kim et al., 2016; Khazi et al., 2018). Spirulina platensis tidak dapat memfiksasi N dari udara karena tidak memiliki heterosis, sehingga pemenuhan kebutuhan $\mathrm{N}$ sangat bergantung pada ketersediaannya di dalam media tumbuh (Rina et al., 2017). Spirulina platensis dapat mengasimilasi berbagai bentuk sumber $\mathrm{N}$ termasuk $\mathrm{NO}_{3}{ }^{-}, \mathrm{NH}_{4}{ }^{+}$, $\mathrm{N}$-organik seperti urea dan asam amino (Kim et al., 2016; Shanthi et al., 2018).

Medium Zarrouk merupakan medium standar bagi budidaya $S$. platensis. Komposisi media ini menggunakan $\mathrm{NO}_{3}{ }^{-}$sebagai sumber $\mathrm{N}$ (Rajasekaran et al., 2016). Penggunaan $\mathrm{NO}_{3}{ }^{-}$ sebagai sumber $\mathrm{N}$ dapat meningkatkan laju pertumbuhan dan produksi biomassa $S$. platensis (Notonegoro et al., 2018; Ulya et al., 2018). Meskipun $\mathrm{NO}_{3}{ }^{-}$umum digunakan sebagai sumber $\mathrm{N}$, beberapa penelitian menunjukkan bahwa urea sebagai sumber $\mathrm{N}$ dapat memberikan pertumbuhan dan kandungan protein yang baik bagi kultivasi $S$. platensis (Putri et al., 2015; Deschoenmaeker et al., 2017; Sukumaran et al., 2018).

Secara umum, urea dapat menjadi sumber $\mathrm{N}$ yang sempurna untuk mendukung pertumbuhan mikroalga biru-hijau, seperti $S$. platensis, yang membutuhkan $\mathrm{N}$ dalam jumlah yang lebih tinggi bila dibandingkan dengan mikroalga hijau (Boussiba, 1989). Layaknya $\mathrm{NO}_{3}^{-}$, urea yang terdapat dalam medium tumbuh mikroalga akan dihidrolisis menjadi $\mathrm{NH}_{4}{ }^{+}$, sehingga dapat dimanfaatkan oleh mikroalga di dalam proses fotosintesis (Sassano et al., 2004). Urea menyediakan jumlah $\mathrm{N}$ yang lebih banyak bila dibandingkan dengan $\mathrm{NO}_{3}{ }^{-}$. Satu molekul urea menyediakan jumlah atom $\mathrm{N}$ yang lebih banyak dibandingkan dengan satu molekul $\mathrm{NO}_{3}{ }^{-}$. Satu molekul urea memiliki 2 atom $\mathrm{N}(46 \% \mathrm{~N})$, sedangkan satu molekul $\mathrm{NO}_{3}{ }^{-}$hanya menyediakan 1 atom N (14-16\% N) (Madkour et al., 2012). Namun, konsentrasi urea yang terlalu tinggi dapat menyebabkan pertumbuhan $S$. platensis terhambat atau bahkan mati (Bao et al., 2012). Hal ini diduga sebagai akibat dari terurainya urea menjadi $\mathrm{NH}_{3}$ bebas yang bersifat toksik pada kondisi basa $(\mathrm{pH}$ $8-8,5$ ) yang optimum bagi pertumbuhan $S$. platensis.

Harga garam $\mathrm{NO}_{3}{ }^{-}$di pasaran biasanya jauh lebih tinggi dibandingkan harga urea (Sassano et al., 2004), terutama pada kondisi rawan keamanan akibat adanya sinyalemen penggunaan $\mathrm{NO}_{3}^{-}$ sebagai bahan peledak. Pada kondisi tersebut, harga garam $\mathrm{NO}_{3}{ }^{-}$dapat meningkat hingga $20 \mathrm{kali}$ lipat. Substitusi sebagian $\mathrm{NO}_{3}^{-}$oleh urea pada komposisi medium Zarrouk dapat meminimalkan biaya media tumbuh dan diharapkan dapat memaksimalkan kultivasi $S$. platensis untuk produksi biomassa, protein dan pigmen fikosianin. Oleh karena itu, berdasarkan penjelasan di atas, maka proses optimasi kombinasi natrium nitrat : urea dan konsentrasi $\mathrm{N}$ dalam medium kultivasi $S$. platensis yang dilakukan pada penelitian ini dihipotesiskan memiliki keunggulan dalam meningkatkan produksi protein dan pigmen fikosianin oleh $S$. platensis dibandingkan kultivasi hanya dengan menggunakan sumber $\mathrm{N}_{-} \mathrm{NO}_{3}{ }^{-}$. Penelitian ini bertujuan untuk mengoptimasi kombinasi natrium nitrat: urea dan konsentrasi $\mathrm{N}$ dalam medium Zarrouk untuk memaksimalkan produksi protein dan pigmen fikosianin oleh $S$. platensis.

\section{Bahan dan Metode}

\section{Mikroalga dan kondisi kultivasi}

Inokulum $S$. platensis yang digunakan pada penelitian ini berasal dari Laboratorium Bioenergi dan Bioproses, Puslit Bioteknologi LIPI Cibinong. Kultur $S$. platensis ditumbuhkan dalam medium Zarrouk (Rajasekaran et al., 2016) yang mengandung $\left(\mathrm{g} \mathrm{L}^{-1}\right) 1,0 \mathrm{NaCl} ; 0,04 \mathrm{CaCl}_{2} .2 \mathrm{H}_{2} \mathrm{O}$; 0,01 $\mathrm{FeSO}_{4} .7 \mathrm{H}_{2} \mathrm{O} ; 0,08$ EDTA (Na); 1,0 Na2 $\mathrm{SO}_{4}$; $0,2 \mathrm{MgSO}_{4} .7 \mathrm{H}_{2} \mathrm{O} ; 16,8 \mathrm{NaHCO}_{3} ; 0,5 \mathrm{~K}_{2} \mathrm{HPO}_{4} ; 1$ $\mathrm{mL}$ larutan mikronutrien yang terdiri dari $\mathrm{H}_{3} \mathrm{BO}_{3}$; $\mathrm{MnCl}_{2} .4 \mathrm{H}_{2} \mathrm{O} ; \quad \mathrm{ZnSO}_{4} .4 \mathrm{H}_{2} \mathrm{O} ; \quad \mathrm{Na}_{2} \mathrm{MoO}_{4}$; $\mathrm{CuSO}_{4} .5 \mathrm{H}_{2} \mathrm{O}$ serta sumber nitrogen berupa $\mathrm{NaNO}_{3}$ dan $\mathrm{CO}\left(\mathrm{NH}_{2}\right)_{2}$ dengan nisbah tertentu. Sianobakteria $S$. platensis dengan nilai Optical Density (OD) awal sebesar 0,1 ditumbuhkan di dalam bejana gelas bening berukuran $500 \mathrm{~mL}$ dengan volume kerja sebanyak $450 \mathrm{~mL}$. Kultivasi dilakukan selama 10 hari pada suhu ruang $\left(27^{\circ} \mathrm{C}\right)$ dengan pencahayaan kontinyu pada intensitas cahaya 25.000 lux (LED cahaya putih, 50 watt), serta diaerasi secara kontinyu. Pertumbuhan mikroalga diamati dengan mengukur nilai OD menggunakan spektrofotometer pada panjang gelombang $680 \mathrm{~nm}$ (Praharyawan \& Putri, 2017). Kultur dipanen pada hari ke-10 dengan metode 
filtrasi menggunakan kain sablon T120 (Prasadi, 2018). Biomassa $S$. platensis dikeringkan dengan menggunakan oven pada suhu $60^{\circ} \mathrm{C}$ selama 48 jam dan bobotnya ditentukan secara gravimetri.

\section{Optimasi nisbah natrium nitrat : urea}

Optimasi nisbah natrium nitrat : urea dilakukan dengan memvariasikan nilai nisbah keduanya seperti terlihat pada Tabel 1. Dasar pemilihan nisbah pada Tabel 1 adalah substitusi sebagian sumber $\mathrm{N}$ oleh urea dimana sebelumnya seluruh sumber $\mathrm{N}$ berasal dari $\mathrm{NaNO}_{3}$. Variasi nisbah yang digunakan diharapkan dapat memberi gambaran bagaimana peran dari masing - masing sumber $\mathrm{N}$ pada perbandingan konsentrasi yang berbeda beda terhadap produksi protein dan pigmen fikosianin oleh $S$. platensis. Konsentrasi sumber N yang digunakan pada tahap ini yaitu 7,6 mmol $\mathrm{L}^{-1}$. Konsentrasi tersebut adalah konsentrasi optimum sumber $\mathrm{N}$ ketika menggunakan $\mathrm{NaNO}_{3}$ dalam kultivasi $S$. platensis. Parameter yang menjadi acuan dalam penentuan nisbah $\mathrm{NaNO}_{3}$ : $\mathrm{CO}\left(\mathrm{NH}_{2}\right)_{2}$ optimum adalah biomassa, protein dan pigmen fikosianin yang dihasilkan dari tiap kondisi eksperimen.

\section{Penelusuran rentang konsentrasi $N$ optimum}

Penelusuran rentang konsentrasi optimum dilakukan setelah nisbah $\mathrm{NaNO}_{3}: \mathrm{CO}\left(\mathrm{NH}_{2}\right)_{2}$ optimum ditemukan. Penelusuran rentang konsentrasi optimum dilakukan dengan cara menelusuri nilai konsentrasi yang dimulai dari konsentrasi N 7,6 mmol L ${ }^{-1}$, baik secara asenden maupun desenden, hingga kurvatur dari respon yang diukur ditemukan. Ada tiga respon yang diukur dalam eksperimen ini, yaitu biomassa, protein dan pigmen fikosianin. Penelusuran rentang konsentrasi $\mathrm{N}$ optimum dilakukan dengan tujuan untuk mendapatkan rentang konsentrasi $\mathrm{N}$ dimana pada rentang tersebut terdapat kurvatur dari respon yang diukur. Kurvatur atau lengkungan, pada kurva hubungan konsentrasi $\mathrm{N}$ dan respon, menandakan bahwa kisaran nilai optimum dari konsentrasi $\mathrm{N}$ untuk menghasilkan respon maksimum berada pada area tersebut.

Optimasi menggunakan Response Surface Methodology (RSM)

Response Surface Methodology (RSM) atau Metodologi Permukaan Respons adalah metode statistik untuk memodelkan dan menganalisis sebuah proses dimana respon yang diinginkan dipengaruhi oleh berbagai faktor, dan metodologi ini dilakukan dengan tujuan untuk mengoptimasi respon (maksimum atau minimum) (Aydar, 2018; Khuri, 2017). Penelitian ini menggunakan RSMone factor dengan tujuan untuk mengoptimasi satu faktor, yaitu konsentrasi $\mathrm{N}$ dalam media termodifikasi untuk kultivasi $S$. platensis, sehingga diharapkan dapat memaksimalkan respon (rendemen protein dan pigmen fikosianin) yang diinginkan (Stanley et al., 2017). Dengan menggunakan perangkat lunak Design eXpert versi 6.0 (DX-6), 8 eksperimen didesain (Tabel 2 dijalankan untuk mendapatkan model hubungan antara faktor dan respon, sehingga dari model tersebut dapat diperoleh nilai faktor optimum untuk mendapatkan respon maksimum.

Tabel 1. Variasi nisbah $\mathrm{NaNO}_{3}: \mathrm{CO}\left(\mathrm{NH}_{2}\right)_{2}$

Table 1. The variation of $\mathrm{NaNO}_{3}: \mathrm{CO}\left(\mathrm{NH}_{2}\right)_{2}$ ratio

\begin{tabular}{cccc}
\hline \multirow{2}{*}{$\begin{array}{c}\text { Perlakuan } \\
\text { Treatment }\end{array}$} & \multicolumn{2}{c}{$\begin{array}{c}\text { Konsentrasi Sumber Nitrogen }\left(\mathrm{mmol} \mathrm{L}^{-1}\right) \\
\text { Nitrogen Source Concentration }(\text { mmol L-1 }\end{array}$} & $\begin{array}{c}\text { Nisbah } \mathrm{NaNO}_{3}: \mathrm{CO}\left(\mathrm{NH}_{2}\right)_{2} \\
\left.\text { Ratio of } \mathrm{NaNO}_{3}: \mathrm{CO}_{(} \mathrm{NH}_{2}\right)_{2}\end{array}$ \\
\cline { 2 - 3 } Kontrol & $\mathrm{NaNO}_{3}$ & $\mathrm{CO}\left(\mathrm{NH}_{2}\right)_{2}$ & - \\
P1 & 4,8 & 0 & $8,5: 1$ \\
P2 & 6,8 & 0,8 & $2,3: 1$ \\
P3 & 5,3 & 2,3 & $1: 1$ \\
P4 & 3,8 & 3,8 & $1: 2,3$ \\
P5 & 2,3 & 5,3 & $1: 8,5$ \\
\hline
\end{tabular}

Tabel 2. Matriks desain eksperimen Response Surface Methodology (RSM) satu faktor

Table 2. Experimental design matrix of Response Surface Methodology (RSM) one factor

\begin{tabular}{ccc}
$\begin{array}{c}\text { Nomor eksperimen } \\
\text { Experimental number }\end{array}$ & $\begin{array}{c}\text { Nilai kode } \\
\text { Coded value }\end{array}$ & $\begin{array}{c}\text { Nilai nyata }\left(\mathrm{mmol} \mathrm{L}^{-1}\right) \\
\text { Actual value }\left(\mathrm{mmol} \mathrm{L}^{-1}\right)\end{array}$ \\
\hline 1 & -1 & 4,75 \\
2 & -1 & 4,75 \\
3 & $-0,5$ & 4,88 \\
4 & 0 & 5,0 \\
5 & 0 & 5,0 \\
6 & 0,5 & 5,13 \\
7 & 1 & 5,26 \\
8 & 1 & 5,26 \\
\hline
\end{tabular}


Analisa statistika hasil eksperimen desain RSMone factor (Tabel 2) dilakukan dengan menggunakan Analyses of Variance (ANOVA) pada perangkat lunak DX-6. Kelayakan model yang diperoleh dapat dilihat dari tingkat signifikansi model serta lack-of-fit pada taraf kepercayaan 95\% $(\mathrm{P}<0,05)$. Analisis model yang didapat harus signifikan, sedangkan taraf lack-offit harus menunjukkan hasil yang tidak signifikan, artinya model yang didapat harus mampu menunjukkan hubungan antara faktor dengan respon.

Verifikasi hasil optimasi protein dan pigmen fikosianin

Verifikasi hasil optimasi dilakukan dengan cara membandingkan konsentrasi $\mathrm{N}$ yang ditemukan oleh desain eksperimen RSM-one factor untuk produksi protein dan pigmen fikosianin dengan media Zarrouk standar sebagai kontrol. Tiga media dengan kosentrasi $\mathrm{N}$ yang berbeda - beda dipersiapkan. Ketiga media tersebut ialah sebagai berikut :

i) Media Zarrouk standar yang mengandung konsentrasi $\mathrm{N}$ sebesar 4,8 $\mathrm{mmol} \mathrm{L}^{-1}$

ii) Media Zarrouk modifikasi dengan konsentrasi $\mathrm{N}$ untuk meningkatkan kandungan protein

iii) Media Zarrouk modifikasi dengan konsentrasi $\mathrm{N}$ untuk meningkatkan kandungan fikosianin

Eksperimen verifikasi untuk masing - masing jenis media dilakukan sebanyak 3 kali ulangan. Analisa statistika uji-t dengan taraf kepercayaan 95\% (P< $0,05)$ dilakukan untuk mengetahui signifikansi perbedaan antara satu perlakuan dengan perlakuannya lainnya menggunakan perangkat lunak Microsoft Excel 2016 (Data Analysis ToolPak).

\section{Prosedur analisis}

\section{Analisis Fikosianin}

Ekstraksi fikosianin dilakukan menggunakan metode freezing-thawing dengan menambahkan buffer fosfat $\mathrm{pH} 7 \mathrm{ke}$ dalam sampel biomassa basah S. platensis (Moraes et al., 2011). Sejumlah biomassa basah $S$. platensis hasil pemanenan dimasukkan ke dalam tabung lalu larutan buffer fosfat $\mathrm{pH} 7$ ditambahkan ke dalamnya. Suspensi biomassa tersebut kemudian divortex lalu dibekukan ke dalam freezer pada suhu $-20^{\circ} \mathrm{C}$ selama \pm 2 jam hingga sampel membeku, selanjutnya thawing dilakukan pada suhu ruang selama \pm 2 jam hingga sampel mencair. Proses freezing-thawing dilakukan sebanyak 2 siklus. Suspensi biomassa hasil freezing thawing kemudian disentrifugasi pada suhu $18^{\circ} \mathrm{C}$ dengan kecepatan $6.000 \mathrm{rpm}$ selama 5 menit untuk memisahkan supernatan dan residunya. Supernatan yang mengandung fikosianin dianalisa menggunakan spektrofotometer UV-Vis
(Shimadzu UV-1700) pada panjang gelombang 620 dan $652 \mathrm{~nm}$ (Chaiklahan et al., 2011). Analisa kandungan kuantitatif pigmen fikosianin dilakukan sebanyak 2 kali ulangan. Konsentrasi fikosianin (mg $\mathrm{mL}^{-1}$ ) dihitung menggunakan persamaan Bennet \& Bogorad (1973) sebagai berikut :

$$
\mathrm{PC}\left(\mathrm{mg} \mathrm{mL}^{-1}\right)=\frac{\left\{\mathrm{A}_{620}-\left(0,474 \times \mathrm{A}_{652}\right)\right\}}{5,34}
$$

Keterangan :

$\mathrm{PC}=$ Konsentrasi fikosianin $\left(\mathrm{mg} \mathrm{mL}^{-1}\right)$

\section{Analisis Protein}

Kandungan protein $S$. platensis dianalisis secara kuantitatif menggunakan metode Bradford (Bradford, 1976). Uji Bradford melibatkan pewarna Coomasie Briliant Blue (CBB) yang akan berikatan dengan protein dalam larutan yang bersifat asam, sehingga akan memberikan warna kebiruan yang selanjutnya diukur secara kolorimetri menggunakan metode spektroskopi $\mathrm{UV}-\mathrm{Vis}$ pada panjang gelombang $595 \mathrm{~nm}$ (Kruger, 1994). Kandungan protein S. platensis dianalisa dari supernatan yang diperoleh dengan metode freezing-thawing, kemudian dikuantifikasi dengan menggunakan kurva standard larutan BSA (Bovine Serum Albumin). Perhitungan kandungan protein dilakukan dengan mensubstitutsi absorbansi sampel protein ke dalam persamaan regresi linear yang didapat dari pengukuran Spektrofotometer $\mathrm{UV}-\mathrm{V}$ is larutan standar BSA $(\mathrm{Y}=0,0034 \mathrm{x}+$ $(-0,017))$. Analisa kandungan kuantitatif protein dilakukan sebanyak 2 kali ulangan.

\section{Hasil dan Pembahasan}

Optimasi nisbah natrium nitrat dan urea dalam medium Zarrouk

Spirulina platensis yang dikultivasi dalam medium standar Zarrouk modifikasi (dengan penambahan urea) menunjukkan pertumbuhan yang lebih baik dibandingkan dengan medium kontrol (tanpa penambahan urea) (Gambar 1). Hal tersebut disebabkan urea dalam medium basa terhidrolisis secara spontan menjadi amonium $\left(\mathrm{NH}_{4}^{+}\right)$karena aktivitas urease dan secara cepat akan diasimilasi oleh $S$. platensis (Dianursanti et al., 2018; Sukumaran et al., 2018). Amonium $\left(\mathrm{NH}_{4}^{+}\right)$secara langsung akan berasimilasi menjadi asam amino dalam sel mikroalga sehingga pembelahan sel akan berjalan lebih cepat (Kim et al., 2016). Hasil yang didapat dalam penelitian ini sejalan dengan penelitian yang dilakukan oleh Soni et al. (2019) yang menyatakan bahwa $S$. platensis yang dikultivasi dalam medium modifikasi dengan penambahan urea sebagai sumber $\mathrm{N}$ memberikan pertumbuhan yang lebih baik dibandingkan medium standar yang hanya menggunakan sumber $\mathrm{N}-\mathrm{NO}_{3}{ }^{-}$. 
Kandungan biomassa kering, protein dan pigmen fikosianin $S$. platensis yang dikultivasi dalam medium Zarrouk modifikasi dan kontrolnya memberikan hasil yang berbeda pada setiap perlakuannya (Tabel 3). Hasil analisis menunjukkan bahwa $S$. platensis yang dikultivasi menggunakan medium Zarrouk modifikasi dengan perbandingan konsentrasi $3,8 \mathrm{mmol} \mathrm{L}^{-1} \mathrm{NaNO}_{3}$ : 3,8 mmol L-1 $\mathrm{CO}\left(\mathrm{NH}_{2}\right)_{2}$ atau nisbah 1:1 (P3) merupakan nisbah optimal. Komposisi medium ini mampu menghasilkan biomassa kering, protein, dan pigmen fikosianin tertinggi dibandingkan dengan nisbah lainnya. Konsentrasi produk yang dicapai berturut-turut: biomassa kering 2,62 $\pm 0,08$ $\mathrm{g} \mathrm{L}^{-1}$; protein $0,52 \pm 0,01 \mathrm{~g} \mathrm{~g}^{-1}$ biomassa, dan pigmen fikosianin $306,94 \pm 10,06 \mathrm{mg} \mathrm{g}^{-1}$ biomassa. Sementara itu, medium kontrol memberikan hasil biomassa kering, protein, dan pigmen fikosianin yang lebih rendah $\left(2,04 \pm 0,28 \mathrm{~g} \quad \mathrm{~L}^{-1}\right.$, $0,24 \pm 0,06 \mathrm{~g}^{-1}$ biomassa, dan 286,28 \pm $14,96 \mathrm{mg} \mathrm{g}^{-1}$ biomassa) dibandingkan dengan hasil dari medium Zarrouk modifikasi. Dalam penelitian ini substitusi sebagian $\mathrm{NO}_{3}{ }^{-}$oleh urea meningkatkan biomassa kering, protein, dan pigmen fikosianin yang diperoleh. Hal ini disebabkan oleh perbedaan kandungan nutrien yaitu berupa sumber $\mathrm{N}$ yang ada dalam medianya. Ketika unsur $\mathrm{N}$ tersedia dalam jumlah cukup maka kebutuhan nutrisi terhadap mikroalga akan terpenuhi sehingga laju pertumbuhannya akan maksimal (Ambarwati et al., 2018; Setyoningrum \& Nur, 2015).

Pada medium kontrol, $S$. platensis hanya dapat memanfaatkan $\mathrm{NO}_{3}{ }^{-}$sebagai sumber $\mathrm{N}$, sedangkan pada medium Zarrouk modifikasi S. platensis akan memanfaatkan urea dan $\mathrm{NO}_{3}{ }^{-}$untuk meningkatkan pertumbuhan dan biosintesis selnya. Urea yang terhidrolisis menjadi bentuk ammonium $\left(\mathrm{NH}_{4}^{+}\right)$ akan terlebih dahulu diasimilasi oleh $S$. platensis sampai habis dalam proses sintesis glutamat

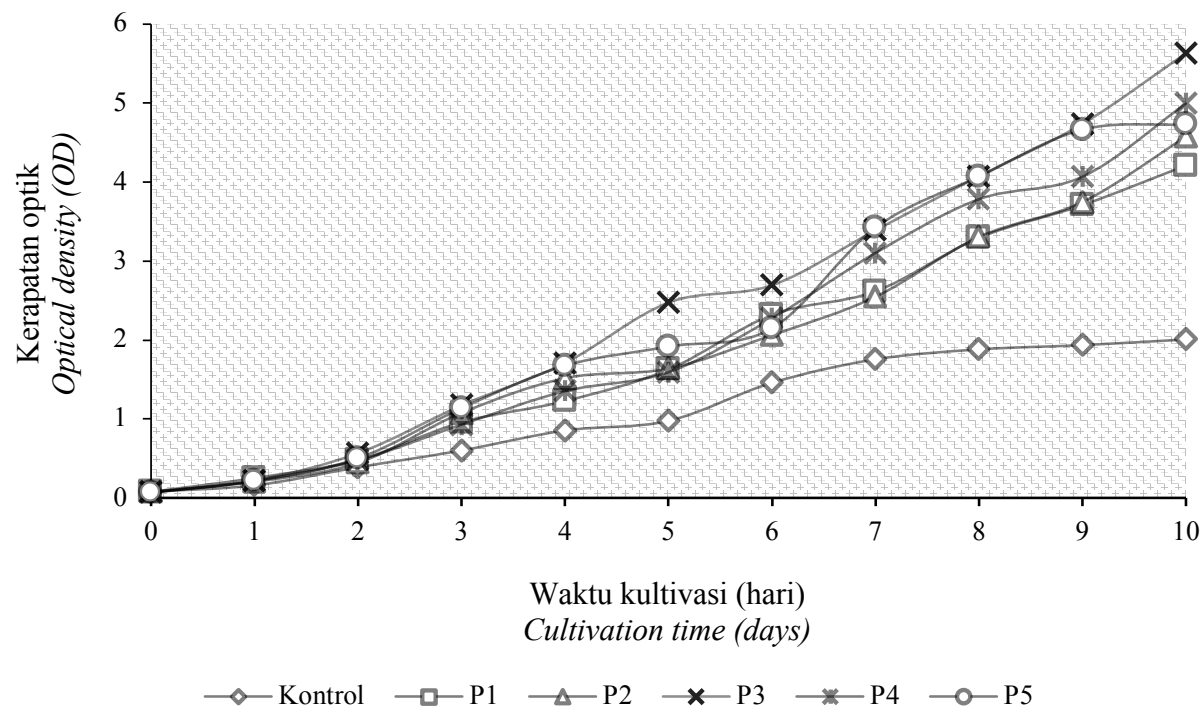

Gambar 1. Kurva pertumbuhan S. platensis dalam medium Zarrouk standar (kontrol) dibandingkan dengan pertumbuhan dalam medium Zarrouk yang dimodifikasi (P1-P5)

Figure 1. Growth curve of S. platensis using standard Zarrouk medium (control) compared to growth in modified Zarrouk medium (P1-P5)

Tabel 3. Kandungan biomassa kering, protein dan pigmen fikosianin S. platensis pada medium Zarrouk standar (kontrol) dan medium Zarrouk yang dimodifikasi selama 10 hari

Table 3. Dry biomass, protein, and phycocyanin content of S. platensis using standard Zarrouk medium (control) and modified Zarrouk medium for 10 days

\begin{tabular}{cccc}
\hline $\begin{array}{c}\text { Perlakuan } \\
\text { Treatment }\end{array}$ & $\begin{array}{c}\text { Biomassa }\left(\mathrm{g} \mathrm{L}^{-1}\right) \\
\text { Biomass }\left(\mathrm{g} \mathrm{L}^{-1}\right)\end{array}$ & $\begin{array}{c}\text { Protein }\left(\mathrm{g} \mathrm{g}^{-1}\right) \\
\text { Protein }\left(\mathrm{g} \mathrm{g}^{-1}\right)\end{array}$ & $\begin{array}{c}\text { Fikosianin }\left(\mathrm{mg} \mathrm{g}^{-1}\right) \\
\text { Phycocyanin }\left(\mathrm{mg} \mathrm{g}^{-1}\right)\end{array}$ \\
\hline Kontrol & $2,04 \pm 0,28$ & $0,24 \pm 0,06$ & $286,28 \pm 14,96$ \\
P1 & $2,10 \pm 0,01$ & $0,53 \pm 0,01$ & $258,89 \pm 18,06$ \\
P2 & $1,78 \pm 0,07$ & $0,40 \pm 0,02$ & $215,45 \pm 6,93$ \\
P3 & $2,62 \pm 0,08$ & $0,52 \pm 0,01$ & $306,94 \pm 10,06$ \\
P4 & $2,01 \pm 0,07$ & $0,49 \pm 0,01$ & $205,74 \pm 12,18$ \\
P5 & $1,88 \pm 0,13$ & $0,47 \pm 0,03$ & $269,76 \pm 4,47$ \\
\hline
\end{tabular}

Keterangan : g. $\mathrm{g}^{-1}$ biomassa $; \mathrm{mg} . \mathrm{g}^{-1}$ biomassa

Notes: $g . g^{-1}$ biomass; $m g . g^{-1}$ biomass 
sehingga pembelahan sel yang terjadi akan lebih cepat, baru setelahnya $S$. platensis akan memanfaatkan $\mathrm{NO}_{3}^{-}$(Kim et al., 2016; Li et al., 2019). Hal ini disebabkan karena hidrolisis urea menjadi amonium $\left(\mathrm{NH}_{4}^{+}\right)$dalam kondisi basa, membutuhkan energi yang lebih sedikit sehingga lebih mudah diasimilasi oleh $S$. platensis (Sukumaran et al., 2018). Di sisi lain, asimilasi $\mathrm{NO}_{3}{ }^{-}$memerlukan energi yang lebih tinggi karena harus melalui dua reaksi reduktif berurutan yang dikatalisis oleh enzim nitrat dan nitrit reduktase sebelum diasimilasi dalam bentuk amonium $\left(\mathrm{NH}_{4}^{+}\right)$ oleh S. platensis (Dianursanti et al., 2018).

Penelitian yang dilakukan oleh MorochoJácome et al. (2016) menunjukkan bahwa penambahan urea secara simultan ke dalam medium kultivasi $S$. platensis yang mengandung $\mathrm{NO}_{3}^{-}$, kandungan protein dan produktivitas biomassa akan meningkat dibandingkan dengan yang hanya menggunakan satu sumber N. Urea sebagai sumber $\mathrm{N}$ tambahan merupakan faktor yang mempengaruhi pertumbuhan sel S. platensis, sehingga memungkinkan pembentukan protein dan fikosianin. Hal ini sesuai dengan yang dinyatakan Soni et al. (2017) bahwa S. platensis dapat tumbuh dalam media yang menggunakan salah satu diantara $\mathrm{NO}_{3}{ }^{-}$atau urea sebagai sumber $\mathrm{N}$, namun apabila keduanya digunakan secara bersamaan akan memberikan keuntungan yang lebih baik bagi kultivasi S. platensis.

\section{Penelusuran rentang konsentrasi $N$ optimum}

Urea yang ditambahkan ke dalam media Zarrouk modifikasi dengan nisbah $\mathrm{NaNO}_{3}$ : $\mathrm{CO}\left(\mathrm{NH}_{2}\right)_{2}$ sebesar 1:1 (P3) dapat digunakan secara efektif pada kultivasi sianobakteri $S$. platensis karena dapat meningkatkan pertumbuhan, produksi biomassa kering, protein serta pigmen fikosianinnya. Konsentrasi yang dimiliki oleh media Zarrouk modifikasi tersebut adalah 7,6 mmol $\mathrm{L}^{-1}$, dimana konsentrasi $\mathrm{N}$ tersebut merupakan konsentrasi optimum sumber $\mathrm{N}$ ketika menggunakan $\mathrm{NaNO}_{3}$ sebagai sumber N-nya. Optimasi konsentrasi $\mathrm{N}$ yang optimum perlu dilakukan untuk meningkatkan kandungan protein dan fikosianin $S$. platensis, sehingga diperlukan penelusuran rentang konsentrasi optimum dimana sumber $\mathrm{N}$ yang digunakan merupakan kombinasi antara $\mathrm{NaNO}_{3}$ dan $\mathrm{CO}\left(\mathrm{NH}_{2}\right)_{2}$.

Penelusuran rentang konsentrasi $\mathrm{N}$ optimum dimulai dari kultivasi $S$. platensis menggunakan konsentrasi $\mathrm{N}$ sebesar 7,6 mmol $\mathrm{L}^{-1}$ untuk kemudian semakin ditingkatkan (asenden) hingga konsentrasi tertentu. Dari hasil yang didapat pada setiap konsentrasi N, kemudian perolehan parameter biomassa kering, protein dan fikosianinnya dibandingkan. Pada konsentrasi $\mathrm{N}$ yang semakin tinggi, parameter pertumbuhannya justru menurun dan bahkan untuk beberapa konsentrasi N S. platensis tidak dapat tumbuh. Oleh karena itu, penelusuran konsentrasi $\mathrm{N}$ selanjutnya dilakukan secara menurun (desenden) pada rentang konsentrasi kurang dari 7,6 mmol L ${ }^{-1}$. Pada rentang konsentrasi tersebut, $S$. platensis menunjukkan adanya peningkatan pertumbuhan, produksi biomassa, protein dan pigmen fikosianin yang lebih baik dibandingkan dengan yang dikultivasi pada konsentrasi $\mathrm{N}$ 7,6 $\mathrm{mmol} \mathrm{L}^{-1}$ (data tidak ditampilkan). Dari hasil penelusuran ditemukan bahwa kisaran $4-5,5 \mathrm{mmol} \mathrm{L}^{-1}$ memberikan kurvatur pada kurva hubungan konsentrasi $\mathrm{N}$ dengan respon biomassa, protein dan pigmen fikosianin (Gambar 2). Kurvatur atau lengkungan, pada kurva hubungan konsentrasi $\mathrm{N}$ dan respon, menandakan bahwa kisaran nilai optimum dari konsentrasi $\mathrm{N}$ untuk menghasilkan respon maksimum berada pada area tersebut. Kurva pada Gambar 2 menunjukkan bahwa kurvatur terdapat di sekitar konsentrasi $\mathrm{N}$

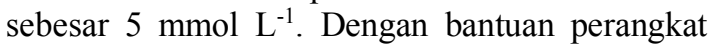
lunak DX-6, maka titik nol konsentrasi $\mathrm{N}$ pada desain eksperimen RSM-one factor selanjutnya dapat ditentukan, yaitu sebesar 5,005 mmol L-1 dengan $\alpha=0,255$. Dengan demikian, rentang konsentrasi $\mathrm{N}$ optimum yang selanjutnya akan dimodelkan dengan menggunakan metode RSMone factor dapat diketahui, yaitu antara 4,75-5,26 mmol L-1.
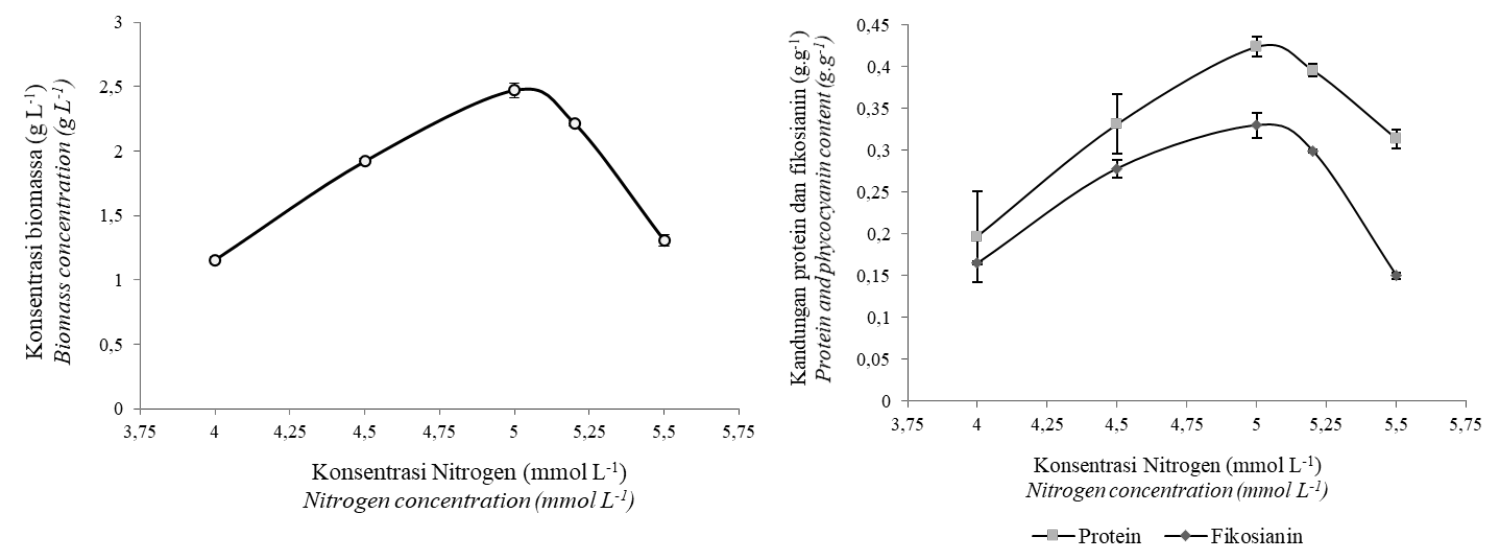

Gambar 2. Kurva hasil penelusuran interval konsentrasi N terhadap: (a) biomassa, (b) protein dan pigmen fikosianin Figure 2. Curve of N concentration interval for: (a) biomass, (b)protein and phycocyanin content 
Rendahnya konsentrasi $\mathrm{N}$ di dalam medium kultivasi akan menyebabkan proses fotosintesis termasuk proses biosintesis protein berjalan tidak optimal, sehingga kandungan protein dan pigmen fikosianin $S$. platensis juga rendah. Pada penelitiannya, Madkour et al. (2012) menyatakan bahwa proses biosintesis protein $S$. platensis meningkat ketika konsentrasi $\mathrm{N}$ dalam medium kultivasi ditingkatkan, namun ketika konsentrasi $\mathrm{N}$ rendah menyebabkan menurunnya senyawa yang dihasilkan dari proses tersebut. Namun, konsentrasi $\mathrm{N}$ yang terlalu tinggi juga dapat menurunkan kandungan protein dan pigmen fikosianin $S$. platensis. Hal itu disebabkan karena sel $S$. platensis sudah mencapai batas maksimum penggunaan nutrien, sehingga proses biosintesis protein menjadi terhambat. Hal tersebut kohern dengan yang dinyatakan oleh Khazi et al. (2018) pada penelitiannya, yaitu ketika konsentrasi $\mathrm{N}$ dalam media kultur ditingkatkan maka kandungan fikobiliprotein dalam sianobakteria juga akan meningkat sampai batas tertentu, namun peningkatan konsentrasi lebih lanjut tidak mempengaruhi produksi fikobiliproteinnya. Spriulina platensis memiliki batas penyerapan N, sehingga apabila konsentrasi $\mathrm{N}$ yang terdapat dalam medium terlalu tinggi maka dapat menghambat proses biosintesis protein di dalam selnya, selain itu jumlah $\mathrm{N}$ yang berlebihan dapat menjadi racun bagi mikroalga itu sendiri (Nurani et al., 2012; Putri et al., 2015).

Optimasi konsentrasi $N$ menggunakan Response Surface Methodology (RSM)-one factor

Optimasi konsentrasi $\mathrm{N}$ pada kultivasi $S$. platensis dilakukan menggunakan desain eksperimen Response Surface Methodology (RSM) one factor dengan konsentrasi N sebagai faktornya. Tahap ini bertujuan untuk mendapatkan konsentrasi $\mathrm{N}$ optimum dan memodelkan hubungannya dengan respon yang diinginkan (protein dan fikosianin) dalam suatu sistem kultivasi $S$. platensis (Xie et al., 2017). Model yang diperoleh kemudian digunakan untuk memprediksi respons (kandungan protein dan pigmen fikosianin) pada kultivasi $S$. platensis menggunakan medium Zarrouk modifikasi. Model polinomial yang dievaluasi mencakup linear, mean, kuadratik, dan kubik, dimana model yang terpilih merupakan model yang paling sesuai dengan hasil pengukuran respons (Faridah et al., 2012). Data pada Tabel 4 menunjukkan total desain percobaan dan hasil respon eksperimen terhadap biomassa, protein dan pigmen fikosianin S. platensis.

Nilai $p$-value merupakan ukuran untuk mengetahui kesesuaian model, semakin kecil nilai $p$-value maka model yang dihasilkan semakin signifikan (Zhao et al., 2011). Nilai $p$-value berdasarkan analisis model polinominal untuk respons protein dan pigmen fikosianin menunjukan bahwa model yang disarankan untuk respons kandungan protein adalah kubik, sedangkan untuk respon kandungan pigmen fikosianin adalah kuadratik. Hasil analisis ragam (ANOVA) terhadap kadar protein dan pigmen fikosianin menunjukkan bahwa model tersebut signifikan ( $p$-value $<0,05)$ (Tabel 5). Hal tersebut menunjukkan bahwa perubahan konsentrasi $\mathrm{N}$ pada rentang yang digunakan dalam model memberikan pengaruh terukur terhadap kandungan protein dan pigmen fikosianin dengan deviasi masih dalam taraf yang diperkenankan secara statistik.

Nilai lack of fit yang tidak signifikan ( $p$-value $>0,05)$ menunjukkan bahwa model yang dihasilkan memiliki pure error yang tidak signifikan, sehingga terdapat kesesuaian data antara respons kandungan protein dan pigmen fikosianin dengan model. Model akan dianggap tidak tepat apabila lack of fit dari model memiliki interpretasi signifikan secara statistik pada taraf $\alpha$ $=0,05$ (Faridah et al., 2012). Persamaan polinomial untuk kedua respons tersebut tertera pada Tabel 5 .

Tabel 4. Hasil respon eksperimen terhadap kandungan biomassa, protein, dan pigmen fikosianin

Table 4. Results of experimental response to biomass, protein and phycocyanin content

\begin{tabular}{cccccc}
\hline $\begin{array}{c}\text { Nomor } \\
\text { eksperimen } \\
\begin{array}{c}\text { Experimental } \\
\text { Number }\end{array}\end{array}$ & $\begin{array}{c}\text { Nilai } \\
\text { kode } \\
\text { Coded } \\
\text { Value }\end{array}$ & $\begin{array}{c}\text { Nilai nyata } \\
\left(\mathrm{mmol} \mathrm{L}^{-1}\right) \\
\begin{array}{c}\text { Actual value } \\
\left(\text { mmol L }^{-1}\right)\end{array}\end{array}$ & $\begin{array}{c}\text { Biomassa }\left(\mathrm{g} \mathrm{L}^{-1}\right) \\
\text { Biomass }\left(\mathrm{g} \mathrm{L}^{-1}\right)\end{array}$ & $\begin{array}{c}\text { Protein }\left(\mathrm{g} \mathrm{g}^{-1}\right) \\
\text { Protein }\left(g g^{-1}\right)\end{array}$ & $\begin{array}{c}\text { Fikosianin }\left(\mathrm{mg} \mathrm{g}^{-1}\right) \\
\text { Phycocyanin }\left(\mathrm{mg} \mathrm{g}^{-1}\right)\end{array}$ \\
\hline 1 & -1 & 4,75 & $2,16 \pm 0,06$ & $0,27 \pm 0,01$ & $299,26 \pm 3,14$ \\
2 & -1 & 4,75 & $2,18 \pm 0,07$ & $0,32 \pm 0,01$ & $304,15 \pm 1,12$ \\
3 & $-0,5$ & 4,88 & $2,19 \pm 0,04$ & $0,26 \pm 0,01$ & $320,51 \pm 1,36$ \\
4 & 0 & 5,0 & $2.06 \pm 0,01$ & $0,33 \pm 0,01$ & $342,18 \pm 0,01$ \\
5 & 0 & 5,0 & $2,17 \pm 0,03$ & $0,35 \pm 0,01$ & $281,84 \pm 0,12$ \\
6 & 0,5 & 5,13 & $1,94 \pm 0,02$ & $0,38 \pm 0,01$ & $263,11 \pm 1,07$ \\
7 & 1 & 5,26 & $1,54 \pm 0,06$ & $0,24 \pm 0,01$ & $256,53 \pm 0,20$ \\
8 & 1 & 5,26 & $1,47 \pm 0,01$ & $0,24 \pm 0,01$ & $289,91 \pm 4,61$ \\
\hline
\end{tabular}

Keterangan: $\mathrm{g} \mathrm{g}^{-1}$ biomassa $; \mathrm{mg} \mathrm{g}^{-1}$ biomassa

Notes: $g^{-1}$ biomass; $m g g^{-1}$ biomass 
Verifikasi hasil optimasi protein dan pigmen fikosianin

Konsentrasi N yang disarankan sebagai konsentrasi optimum berdasarkan hasil optimasi menggunakan RSM one factor untuk meningkatkan kandungan protein dan pigmen fikosianin S. platensis yaitu sebesar $5,13 \mathrm{mmol} \mathrm{L}^{-1}$ dan $4,94 \mathrm{mmol} \mathrm{L}^{-1}$, secara berturut-turut. Validasi model kemudian dilakukan dengan membandingkan kultur $S$. platensis yang dikultivasi menggunakan konsentrasi optimum dengan kultur yang dikultivasi menggunakan medium Zarrouk standard sebagai kontrol (Tabel 6). Hasil validasi data yang diperoleh menunjukkan bahwa terdapat perbedaan secara signifikan antara kandungan protein dan pigmen fikosianin yang diperoleh dari persamaan model optimumnya $(p$-value $<0,05)$.

Medium Zarrouk dengan konsentrasi N optimum meningkatkan kandungan protein dan pigmen foksianin S. platensis hingga $51,95 \%$ dan $25,16 \%$, secara berturut-turut. Prabuthas et al., (2011) pada penelitiannya yang mengoptimasi faktor lingkungan (suhu, cahaya, jumlah inokulum, dan waktu kultivasi) untuk kultivasi S. platensis meningkatkan kandungan protein hingga 58,46\%. Pada penelitian Setyoningrum \& Nur (2015), S. platensis yang dikultivasi menggunakan konsentrasi urea dan molase yang optimum meningkatkan kandungan fikosianin hingga 17,2\%. Penelitian yang dilakukan oleh Xie et al. (2017) menunjukkan bahwa Chlorella vulgaris yang dikultivasi dengan kondisi media yang optimal meningkatkan kandungan protein hingga $44,3 \%$. Hal tersebut menunjukkan bahwa ketika konsentrasi $\mathrm{N}$ dalam medium kultivasi ada dalam level optimum, maka aktivitas metabolisme termasuk biosintesis protein $S$. platensis juga akan berjalan dengan baik (Amanatin \& Nurhidayati, 2013).

Pada penelitian ini, peningkatan fikosianin pada media optimum hanya $25,16 \%$ atau setengah dari peningkatan protein yang sebesar $51,95 \%$. Hal itu disebabkan oleh kondisi lingkungan kultivasinya yang tidak terlalu mendukung $S$. platensis dalam memproduksi dan mengakumulasi fikosianin. Manirafasha et al. (2018) menggunakan strategi penambahan senyawa sodium glutamat yang dikombinasikan dengan pengumpanan nitrat secara fed-batch dalam meningkatkan produksi pigmen fikosianin dan biomassa S. platensis. Hal berbeda ditempuh oleh Sivasankari et al. (2020) yang mengiluminasi kultur S. platensis menggunakan LED warna merah dalam meningkatkan produksi dan akumulasi fikosianinnya.

Tabel 5. Analisis model untuk respon protein dan pigmen fikosianin

Table 5. Analysis model for protein and phycocyanin response

\begin{tabular}{|c|c|c|c|c|}
\hline $\begin{array}{l}\text { Respon } \\
\text { Response }\end{array}$ & $\begin{array}{l}\text { Persamaan } \\
\text { Equation }\end{array}$ & $\begin{array}{c}\text { Sumber } \\
\text { Source }\end{array}$ & $\begin{array}{l}\text { Prob }>\text { F } \\
\text { Prob }>F\end{array}$ & $\begin{array}{l}\text { Model } \\
\text { Model }\end{array}$ \\
\hline Protein & $\begin{array}{c}Y=1404,47609-848,41227 x+ \\
170,73973 x^{2}-11,44457 x^{3}\end{array}$ & $\begin{array}{l}\text { Sequential p-value } \\
\text { Lack of fit p-value } \\
\text { Adjusted R-Squared } \\
\text { Predicted R-Squared }\end{array}$ & $\begin{array}{l}0,0072^{\mathrm{a}} \\
0,8982^{\mathrm{b}} \\
0,8906 \\
0,7631\end{array}$ & Kubik \\
\hline Fikosianin & $\begin{array}{c}Y=(-15432,67)+6372,6867 x- \\
644,4399 x^{2}\end{array}$ & $\begin{array}{l}\text { Sequential p-value } \\
\text { Lack of fit p-value } \\
\text { Adjusted R-Squared } \\
\text { Predicted R-Squared }\end{array}$ & $\begin{array}{l}0,0154^{\mathrm{a}} \\
0,1181^{\mathrm{b}} \\
0,7361 \\
0,6192\end{array}$ & Kuadratik \\
\hline
\end{tabular}

(a) Model Signifikan; ${ }^{b}$ ) lack of fit tidak signifikan

( ${ }^{(a)}$ Significant model ; $\left({ }^{b}\right)$ lack of fit is not significant

Tabel 6. Perbandingan kandungan protein dan pigmen fikosianin S. platensis pada konsentrasi optimum dan kontrol Table 6. Comparison of protein and phycocyanin content of S. platensis optimum concentration and control

\begin{tabular}{|c|c|c|c|c|c|}
\hline \multirow[t]{2}{*}{ 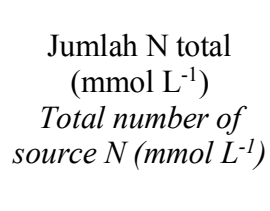 } & \multicolumn{2}{|c|}{$\begin{array}{l}\text { Konsentrasi sumber } \mathrm{N} \\
\left(\mathrm{mmol} \mathrm{L}^{-1}\right) \\
\text { N source concentration } \\
\left(\text { mmol L } \mathrm{L}^{-1}\right)\end{array}$} & \multirow[t]{2}{*}{$\begin{array}{c}\text { Biomassa }\left(\mathrm{g} \mathrm{L}^{-1}\right) \\
\text { Biomass }\left(\mathrm{g} \mathrm{L}^{-1}\right)\end{array}$} & \multirow[t]{2}{*}{$\begin{array}{l}\text { Protein }\left(\mathrm{g} \mathrm{g}^{-1}\right) \\
\text { Protein }\left(g^{-1}\right)\end{array}$} & \multirow[t]{2}{*}{$\begin{array}{l}\text { Fikosianin }\left(\mathrm{mg} \mathrm{g}^{-1}\right) \\
\text { Phycocyanin }\left(\mathrm{mg} \mathrm{g}^{-1}\right)\end{array}$} \\
\hline & $\mathrm{NaNO}_{3}$ & $\mathrm{CO}\left(\mathrm{NH}_{2}\right)_{2}$ & & & \\
\hline 4,80 & 4,80 & 0 & $1,39 \pm 0,04$ & $0,19 \pm 0,01$ & $185,59 \pm 1,81$ \\
\hline $4,94^{\mathrm{a}}$ & 2,47 & 2,47 & $1,61 \pm 0,01$ & $0,19 \pm 0,01$ & $232,28 \pm 1,97$ \\
\hline $5,13^{b}$ & 2,57 & 2,57 & $1,79 \pm 0,05$ & $0,29 \pm 0,01$ & $195,85 \pm 4,18$ \\
\hline
\end{tabular}

${ }^{(a)}$ Konsentrasi N optimum untuk pigmen fikosianin ; $\left({ }^{b}\right)$ Konsentrasi $\mathrm{N}$ optimum untuk protein

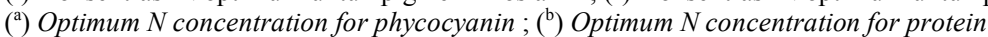




\section{Kesimpulan}

Berdasarkan hasil penelitian dapat disimpulkan bahwa substitusi sebagian sumber $\mathrm{N}_{-} \mathrm{NO}_{3}^{-}$oleh urea pada medium Zarrouk dapat meningkatkan dan mengoptimalkan produksi protein dan pigmen fikosianin oleh sianobakteria $S$. platensis. Nisbah natrium nitrat : urea optimum bagi kultivasi Spirulina platensis dalam meningkatkan produksi pigmen fikosianin dan protein adalah pada nisbah $1: 1$. Konsentrasi $\mathrm{N}$ optimum dalam medium Zarrouk untuk meningkatkan produksi protein pada kultivasi $S$. platensis yaitu sebesar $5,13 \mathrm{mmol} \mathrm{L}^{-1}$ dengan peningkatan sebanyak $51,95 \%$, sedangkan untuk meningkatkan produksi pigmen fikosianin yaitu sebesar $4,94 \mathrm{mmol} \mathrm{L}^{-1}$ dengan peningkatan sebesar $25,16 \%$.

\section{Daftar Pustaka}

Amanatin DR \& T Nurhidayati (2013). Pengaruh kombinasi konsentrasi media ekstrak tauge (MET) dengan pupuk urea terhadap kadar protein Spirulina sp. Jurnal Sains dan Seni POMITS 2(2), 2-5.

Ambarwati DP, E Yudiati, E Supriyantini \& L Maslukah (2018). Pola pertumbuhan, biomassa dan kandungan protein kasar kultur Skeletonema costatum skala massal dengan konsentrasi kalium nitrat berbeda. Buletin Oseanografi Marina 7(2), 75.

Avila-Leon I, M Chuei Matsudo, S Sato \& JCM de Carvalho (2012). Arthrospira platensis biomass with high protein content cultivated in continuous process using urea as nitrogen source. Journal of Applied Microbiology 112(6), 1086-1094.

Aydar, AY (2018). Utilization of response surface methodology in optimization of extraction of plant materials. In : Silva, V. (ed) Statistical Approaches With Emphasis on Design of Experiments Applied to Chemical Processes, p. 157.

Bao Y, S Wen, W Cong, X Wu \& Z Ning (2012). An optical-density-based feedback feeding method for ammonium concentration control in Spirulina platensis cultivation. J. Microbiol Biotcehnol 22(7), 967-974.

Bennett A \& L Bogobad (1973). Complementary chromatic adaptation in a filamentous bluegreen alga. Journal of Cell Biology 58(2), 419435 .

Boussiba S (1989). Ammonia uptake in the alkalophilic cyanobacterium Spirulina platensis. Plant and Cell Physiology 30(2), 303-308.

Bradford MM (1976). A rapid and sensitive method for the quantitation of microorganism quantities of protein in utilizing the principle of protein-dye binding. Anal Biochem 72, 248254.

Chaiklahan R, N Chairasuwan \& B Bunnag (2012). Stability of phycocyanin extracted from Spirulina sp: influence of temperature, $\mathrm{pH}$ and preservatives. Process Biochemistry 47, 659-664.

Chaiklahan R, N Chirasuwan, V Loha, S Tia \& B Bunnag (2011). Separation and purification of phycocyanin from Spirulina sp. using a membrane process. Bioresource Technology 102, 7159-7164.

Deschoenmaeker F, G Bayon-Vincente, N Sachedeva, O Depraetere, JC Cabrera Pino, B Leroy, K Muylaert \& R Wattiez (2017). Impact of different nitrogen sources on the growth of Arthrospira sp. PCC 8005 under batch and continuous cultivation-a biochemcial, transcriptomic and proteomic profile. Bioresource Technology 237, 78-88.

Dianursanti, Z Taurina \& CM Indraputri (2018). Optimization growth of Spirulina platensis in bean sprouts extract medium with urea fertilizer for phycocyanin production as antioxidant. In : AIP Conference Proceedings, 1933.

Faridah A, SB Widjanarko, A Sutrisno \& B Susilo (2012). Optimasi produksi tepung porang dari chip porang secara mekanis dengan metode permukaan respons. Jurnal Teknik Industri 13(2), 158-166.

Khazi MI, Z Demirel \& MC Dalay (2018). Evaluation of growth and phycobiliprotein composition of cyanobacteria isolates cultivated in different nitrogen sources. Journal of Applied Phycology 30(3), 15131523.

Khuri AI (2017). A general overview of response surface methodology. Biometrics \& Biostatistics International Journal 5(3), 87-93.

Kim G, G Mujtaba \& K Lee (2016). Effects of nitrogen sources on cell growth and biochemical composition of marine chlorophyte Tetraselmis sp. for lipid production. Algae 31(3), 257-266.

Kruger NJ (1994). The bradford method for protein quantitation. In: Walker JM. The Protein Protocols Handbook: Second Edition, p 15.

Li X, W Li, J Zhai, H Wei \& Q Wang (2019). Effect of ammonium nitrogen on microalgal growth, biochemical composition and photosynthetic performance in mixotrophic cultivation. Bioresource Technology, 368-376.

Madkour FF, AE Kamil \& HS Nasr (2012). Production and nutritive value of Spirulina 
platensis in reduced cost media. Egyptian Journal of Aquatic research 38, 51-57.

Manirafasha E, T Murwanashyaka, T Ndikubwimana, NR Ahmed, J Liu, Y Lu, X Zeng, X Ling \& K Jing (2018). Enhancement of cell growth and phycocyanin production in Arthrospira (Spirulina) platensis by metabolic stress and nitrate fed-batch. Bioresource Technology 255, 293-301.

Moraes CC, L Sala, GP Cerveira \& SJ Kalil (2011). C-Phycocyanin extraction from Spirulina platensis wet biomass. Brazilian Journal of Chemical Engineering 28(1), 45-49.

Morocho-Jácome AL, S Sato, L Guimarães, CKC de Jesus \& JCM de Carvalho (2016). Simultaneous use of sodium nitrate and urea as nitrogen sources improves biomass composition of Arthrospira platensis cultivated in a tubular photobioreactor. Engineering in Life Sciences 16, 338-347.

Notonegoro H, I Setyaningsih \& K Tarman (2018). Kandungan senyawa aktif Spirulina platensis yang ditumbuhkan pada media walne dengan konsentrasi $\mathrm{NaNO}_{3}$ berbeda. Jurnal Pascapanen dan Bioteknologi Kelautan dan Perikanan 13(2), 111.

Nurani FR, ED Masithah \& AS Mubarak (2012). Pengaruh konsentrasi pupuk Azolla piñata terhadap pertumbuhan populasi Spirulina platensis. Jurnal Ilmu Perikanan dan Kelautan 4, 39-44.

Prabuthas P, PP Srivastav \& HN Mishra (2011). Optimization of environmental factor using RSM for Spirulina platensis cultivation. Nutrition \& Food Science 41(3), 175-182.

Praharyawan S \& SA Putri (2017). Optimasi efisiensi flokulasi pada proses panen mikroalga potensial penghasil biodiesel dengan flokulan ion magnesium. Biopropal Industri 8(2), 8998 .

Prasadi O (2018). Pertumbuhan dan biomasa Spirulina sp. dalam media pupuk sebagai bahan pangan fungsional. Jurnal Ilmiah Perikanan dan Kelautan 10(2), 119-123.

Putri MP, S Syukur \& Z Chaidir (2015). Penggunaan sumber nitrogen terhadap kandungan protein dan asam amino pada mikroalga Spirulina platensis. Jurnal Kimia Unand 4(2), 11-17.

Rahman DY, FD Sarian, A van Wijk, M MartinezGarcia \& MJEC van der Maarel (2017). Thermostable phycocyanin from the red microalga Cyanidioschyzon merolae a new natural blue food colorant. Journal of Applied Phycology 29(3), 1233-1239.

Rajasekaran C, CPM Ajeesh, S Balaji, M Shalini, $\mathrm{R}$ Siva, R Das, DP Fulzele \& $\mathrm{T}$ Kalaivani
(2016). Effect of modified zarrouk's medium on growth of different Spirulina strain. Walailak J Sci \& Tech 13(1), 67-75.

Richmond A (1988). Spirulina. In: Borowitzka MA \& LJ Borowitzka. Micro-algal Biotechnology, p 85-121.

Rina T, A Putri, Karmiati, S Sundari, A Saputri (2017). Organik suplemen tinggi protein berbahan dasar Spirulina sp dengan media kultur limbah cair industri kecap. Jurnal Jeumpa 4(1), 80-91.

Rodrigues MS, LS Ferreira, A Converti, S Sato \& JCM de Carvalho (2011). Influence of ammonium sulphate feeding time on fed-batch Arthrospira (Spirulina) platensis cultivation and biomass composition with and without $\mathrm{pH}$ control. Bioresource Technology 102(11), 6587-6592.

Saleh AM, DW Dhar \& PK Singh (2011). Comparative pigment profiles of different Spirulina strains. Research in Biotechnology, 2(2), 67-74.

Sassano CEN, JCM Carvalho, LA Gioielli, S Sato, P Torre \& A Converti (2004). Konetics and bioenergetics of Spirulina platensis cultivation by fed-batch addition of urea as nitrogen source. Applied Biochemistry and Biotechnology 112, 143-150.

Seo YC, WS Choi, JH Park, JO Park, KH Jung \& HY Lee (2013). Stable isolation of phycocyanin from Spirulina platensis associated with high pressure extraction process. International Journal of Molecular Sciences 4, 1778-1787.

Setyoningrum TM \& MMA Nur (2015). Optimization of c-phycocyanin from $S$. platensis cultivated on mixotrophic condition by using response surface methodology. Biocatalysis and Agricultural Biotechnology 4, 603-607.

Shanthi G, M Premalatha \& N Anantharaman (2018). Effects of L-amino acids as nitrogen source on the growth rate, biochemcial composition and polyphenol content of Spirulina platensis. Algal Research 35, 471478.

Sivasankari S, M Vinoth, D Ravindran, K Baskar, AA Alqarawi \& EF Abd_Allah (2020). Efficacy of red light for enhanced cell disruption and fluorescence intensity of phycocyanin. Bioprocess and Biosystem Engineering.

Soni RA, K Sudhakar \& RS Rana (2017). Spirulina-from growth to nutritional product: a review. Trends in Food Science and Technology 69, 157-171. 
Soni RA, K Sudhakar \& RS Rana (2019). Comparative study on the growth performance of Spirulina platensis on modifying culture media. Energy Reports 5, 327-336.

Stanley HO, CB Ogbonna \& GO Abu (2017). Exploration of one-factor rsm to optimize the concentration of organic fraction of municipal solid waste (OFMSW) for biogas production. International Journal of Waste Resources 7, 293.

Sukumaran P, R Nuli, N Halimoon, S Simoh, H Omar \& A Ismail (2018). Formulation of costeffective medium using urea as a nitrogen source for Arthospira platensis cultivation under real environment. Annual Research \& Review in Biology 22(2), 1-12.
Ulya S, S Sedjati \& E Yudiati (2018). Kandungan protein Spirulina platensis pada media kultur dengan konsentrasi nitrat $\left(\mathrm{KNO}_{3}\right)$ yang berbeda. Buletin Oseanografi Marina 7(2), 98.

Xie T, Y Xia, Y Zeng, X Li \& Y Zhang (2017). Nitrate concentration-shift cultivation to enhance protein content of heterotrophic microalga Chlorella vulgaris: overcompensation strategy. Bioresource Technology 233, 247-255.

Zhao O, JF Kennedy \& X Wang (2011). Optimization of ultrasonic circulating extraction of polysaccharides from Asparagus Officinalis using response surface methodology. International Journal of Biological Macromolecules 49, 181-187. 